\title{
Writing the Selfie: Using Selfies to Practice Character Presentation and Rhetorical Discourse
}

\author{
Simone Sessolo* \\ $06 / 20 / 2018^{\dagger}$
}

\begin{abstract}
The Selfie Project" is the final assignment in an upper-level undergraduate course on writing with digital and social media. The assignment intends to increase students' awareness of their everyday practices by asking them to critically analyze the act of taking pictures of themselves. Selfies have become an integral part of students' daily lives. For example, students post selfies on social media, they take selfies at parties and on vacation, and they use them to connect with their communities. Though they might seem inconsequential, selfies are rhetorically rich sites of character presentation in the world of social media: practicing their composition offers students a novel way to enhance understanding of character presentation in social media. With this assignment, students successfully brainstorm, compose, and revise rhetorical content in a genre they are already culturally familiar with.
\end{abstract}

"The Selfie Project" is the final assignment for the class Writing the Selfie, an upper-level undergraduate course under the umbrella of Writing 200 courses offered by the Sweetland Center for Writing at the University of Michigan. Writing 200 courses encourage students to write with images and examine the interplay of the text and image. Students take these courses to fulfill their minors in writing and digital studies. As one of the teachers of writing with digital and social media courses, I designed a class centered on practicing writing strategies via taking selfies. The main goals of the course are to demonstrate the ability to rhetorically analyze selfies as acts of communication using appropriate nomenclature and to demonstrate an understanding of composing effective selfies. So, the class is designed to focus on the selfie as an utterance that participates in rhetorical

\footnotetext{
${ }^{*}$ Sweetland Center for Writing, University of Michigan, sessolo@umich.edu. Copyright 2018 Simone Sessolo. This work is licensed under a Creative Commons Attribution-NonCommercial 4.0 International License (http://creativecommons.org/licenses/by-nc/4.0/).

${ }^{\dagger}$ Submitted, 07/20/2017; Accepted, 01/02/2018.
} 
discourse, and we attempt to apply discursive categories inherited from classical rhetoric to the selfie as a visual text. The classical discourses we consider are: epideictic, i.e. the act of praising or blaming something in the present moment; deliberative, i.e. the effort to convince an audience to do/feel something in the future; and forensic, i.e. the offering of evidence that proves that something happened in the past. To these, we add a fourth one derived from postmodern rhetoric: discursive formation. ${ }^{1}$ The class introduces students to elements of classical rhetoric and recent literature relevant to the selfie phenomenon, and we bring the two conversations together, using the one to understand the other. In class, we try to answer these specific questions: What do we want to communicate when we take a selfie? And how does that act of communication affect the way we present ourselves to our communities? The primary purpose of "The Selfie Project" is to provide an opportunity for students to use selfies as strategies of character presentation. A secondary purpose is to offer students a novel possibility to gain awareness of how they self-represent, argue, and make meaning in social media. ${ }^{2}$

The class is organized in three units that form a scaffolding structure leading to the final assignment, "The Selfie Project." In Unit 1, "Situating the Selfie," students engage with recent texts and studies about the cultural phenomenon of the selfie. These readings range from studies in multimodality that attempt to define the selfie as a genre with specific visual conventions, such as tilting the head and smiling, to poems and blog posts that focus on personality traits of the selfie-taker, such as narcissism and vanity. The purpose of this unit is to engage with readings that help students to think critically about this recently popularized mode of expression. In short, we situate the selfie as a cultural and social event by understanding the means by which it communicates. The students' task for this unit is to explore the selfie with an open mind, question assumptions that they might not find convincing in the readings, and create connections between the readings and the students' personal worlds. In particular, we look at websites such as Selfiecity, Selfieresearchers, and 365 Feminist Selfie; we read texts such as Saltz's (2014) "Art at Arm's Length: A History of the Selfie" and Modery's (2015) "Why We Should 'Like' Experiences-Not Selfies"; and we discuss the selfie as a genre by reading and talking about Deep Neural Networks (computer systems that re-enact the thinking of the brain) in order to consider the reception of its formal features. ${ }^{3}$

Most importantly, this unit provides the opportunity to consider how current discussions about the selfie, both scholarly and non-scholarly, mostly treat the selfie as a cultural and aesthetic phenomenon. The poet Frieda Hughes, for example, ends her poem "Selfie" (2015) with the verse "but forever with your back to it," implying that the culture of selfie-taking is one in which people do not directly participate in events, but only record them. About the aesthetics of the selfie, Andrej Karpathy's (2015) study on using deep neural networks in "reading" the selfie suggests that to take a good selfie people should "be female... Face should occupy about $1 / 3$ of the image... Cut off your forehead... Show your long hair... Oversaturate the face... Put a filter on it... Add a border." These readings seem to offer quite a deterministic vision of selfies and selfie-takers. Therefore, we conclude the unit by asking: Can we see the selfie also as an 
act of composition? Often, since taking a selfie is a quick action that does not involve a high level of self-reflection, we overlook the fact that even such an instantaneous activity requires a certain degree of brainstorming, composing, and revising - even though these stages might happen at a subconscious level.

Consequently, in Unit 2, "Decoding Discourses," students consider the selfie as an act of composition. To do that, they explore rhetorical discourses that they use to purposefully communicate with an audience. In this unit, students actively engage with one specific kind of discourse: epideictic, deliberative, forensic, or postmodern. Students have the freedom to choose and research in groups one type of rhetorical discourse and then lead a class session on that discourse. Students have the choice to study in depth whatever discourse appeals to them the most, based also on their major and how that discourse would affect their future professions, because different professions engage primarily with specific discourses. For example, a student who majored in history, or in a STEM field, might research forensic discourse, considering the importance of factual evidence in those fields. In short, these class presentations serve as a sort of professional development, and students (under my supervision) are free to organize our class session in any way they like. Furthermore, these presentations offer students the opportunity to learn from each other, giving them authority to actively engage in the collaborative creation of knowledge.

In Unit 2, we also introduce issues of character presentation, considering that we use selfies to present ourselves to an audience. We start from the classical concept of ethos: the skilled presentation of an author's character. In order to ground our practice and understanding in the rhetorical tradition, we read excerpts from Cicero's De Oratore, Quintilian's Institutes of Oratory, Isocrates' Antidosis, Aristotle's Rhetoric, Burke's A Rhetoric of Motives, and Foucault's The Archaeology of Knowledge. ${ }^{4}$ The purpose of these readings, paired with students' research on specific rhetorical discourses, is to consider the differences between establishing character via the conventional rules for print and via the unsettled ones for online discourse. These are not easy readings, and class discussions are usually vibrant and challenging.

Our discussions help us to establish four categories that connect issues of character presentation and rhetorical discourse, in order to set up a nomenclature that students can follow: good character, persuasion, identification, and discursive formation. Good character establishes traits of epideictic rhetoric, whose aim is to celebrate the present, praising the subject of the selfie for their good nature in an impromptu moment. ${ }^{5}$ Persuasion denotes a selfie that engages in deliberative rhetoric, whose aim is to change the future, convincing the audience that one of the subject's actions delivers good results. Identification sets up practices in forensic rhetoric, whose aim is to understand the past, creating a connection between the subject, the audience, and a recognizable discourse community. Finally, discursive formation allows the human subject to speak through an object.

The complexity of understanding and practicing these categories is that, as is the case in traditional rhetoric, each discursive attempt includes aspects of all these categories. It is 
good to spend a fair amount of class time coming to terms with the fact that an act of composition that is mostly persuasive can include epideictic and forensic aspects as well. As an example, consider this selfie, taken by a participant in the course and reproduced here with permission:

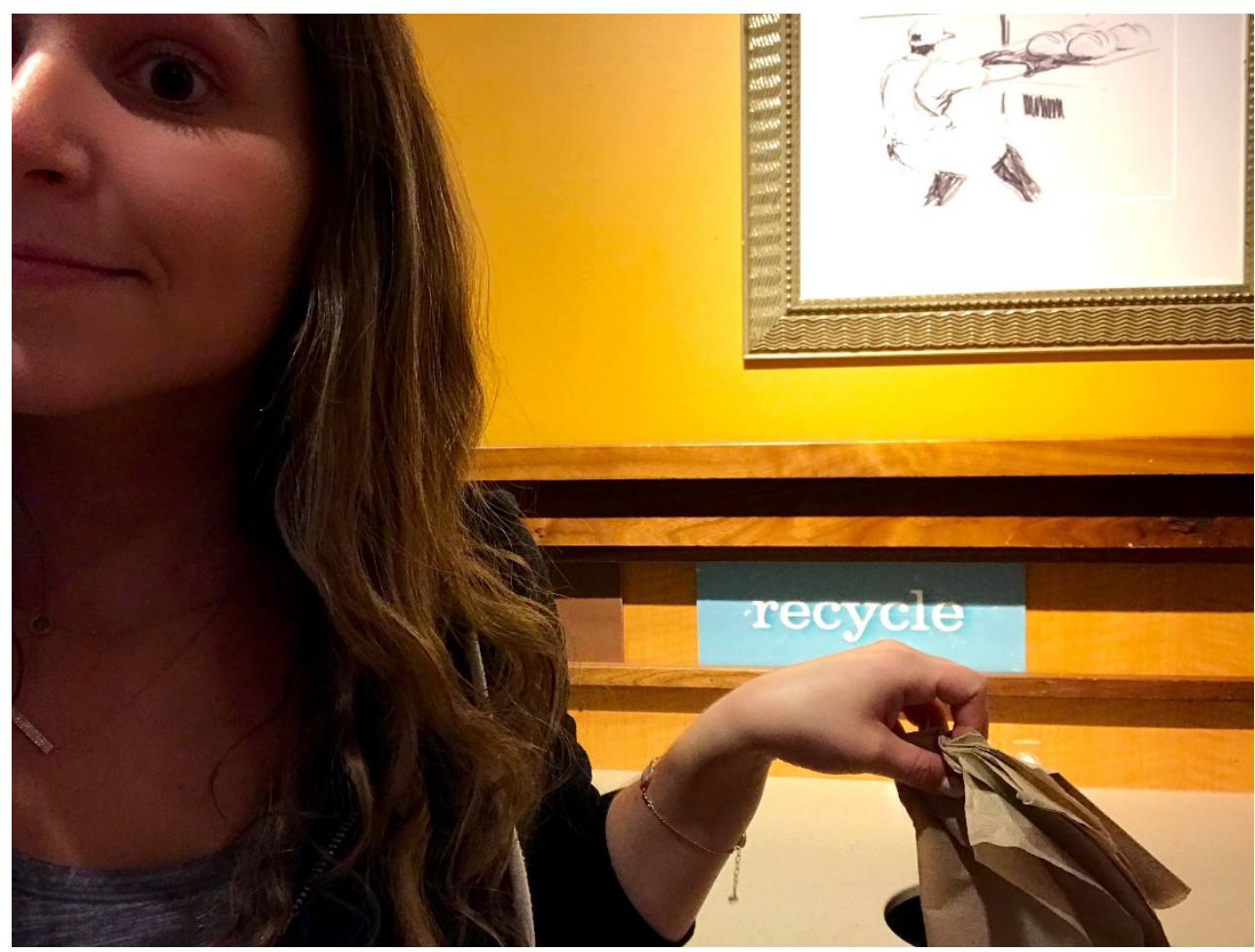

Figure 1: Discourses in a Selfie

Here the subject of the selfie is shown recycling some paper. Therefore, an audience could infer that the subject wants to convince other people to recycle, as she does. In this case, audiences could read this selfie as deliberative, since they can also see the sign "recycle" that might be interpreted as a command. However, recycling can also be seen as an activity that shows a good personal trait such as caring for the environment; therefore, audiences could read this selfie as participating in epideictic discourse as well. At this point, audiences are faced with a choice: Which discourse appears to be stronger in the communication between the subject and her audience? In this specific case, since we have the visual presence of the verbal command "recycle," viewers might be led to think that yes, they should recycle too.

With selfies, as in written rhetoric, these discourses do not occur in a vacuum. As the selfie above shows, a selfie can be situated as part of a specific rhetorical discourse, but it is highly possible that audiences can see aspects of different rhetorical discourses in that same selfie. This awareness helps students to reflect purposefully on what discourse they want to be the dominant one in their selfies. It prepares them for the final assignment for 
the course: taking selfies to present aspects of their character through a chosen rhetorical discourse.

Once students understand the link between character presentation and rhetorical discourses, they are ready to move from theory to practice and start working on "The Selfie Project" assignment in Unit 3, "Performing Personae." This unit, which works as a series of workshops and peer reviews, is the culmination of the readings introduced in Unit 1 and the discourses practiced in Unit 2. In these workshops, students practice taking selfies that they might use for their final assignment. The assignment asks students to collate four selfies, one for each rhetorical discourse, in a platform of their choice, depending on their technological literacy: Students can experiment with a website design platform, such as Wix or Wordpress, or they can use a presentation platform such as Prezi or PowerPoint. In order to come up with those four selfies students engage in a series of in-class hands-on activities. The members of the class are the intended audience for the assignment, and they work as a representative sample of the students' college community. For the selfie on good character, I allow students 20 minutes of class time to wander around campus and take a selfie that shows a specific positive aspect of the author's character. When students come back to class, I pair them and have them write captions for each other's selfies about the aspect of the person's character they see. Since the class has a seminar format, at this point in the semester students know each other quite well, and they can act as participants in a shared social circle, the same way many "contacts" in social networks do in responding to posted selfies. After this activity, students check if the audience's caption matches their intention and discuss what elements in the selfie communicate that positive trait of the author's character. ${ }^{6}$ This exercise allows students to reflect on how an audience interprets character presentation. For the selfie on persuasion, I allow 20 minutes of class time for students to brainstorm about activities that reveal aspects of their character. Students think about how that activity reveals their character and why that activity results in positive outcomes. Referring back to Figure 1 above, a positive outcome would be that there is less trash in the world, leading to a cleaner environment.

For the selfie on identification we use a basic identity wheel. The wheel has a number of cells in which students insert some of the traits that define their identities: nationality, gender, school major, club or organization affiliation, and so on. 


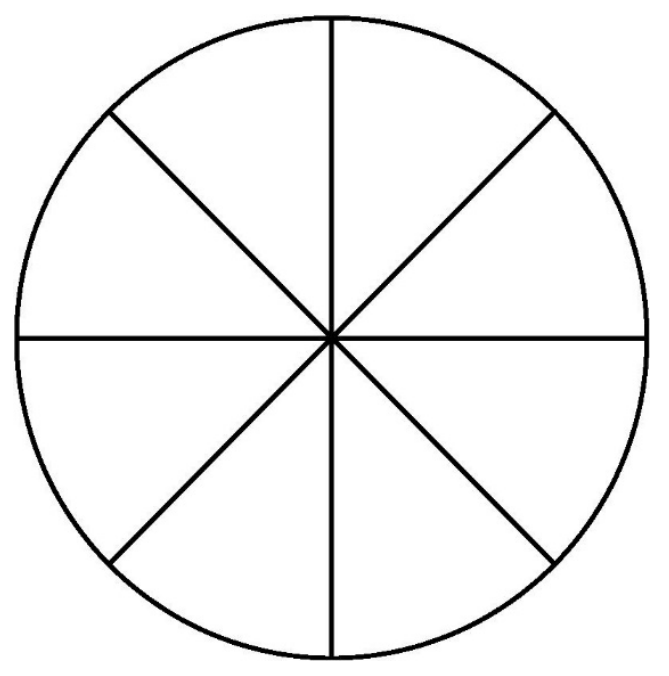

Figure 2: Basic Identity Wheel

After students fill their cells, I ask them to identify the discursive community they want to engage with their selfies and then choose one symbol that would create identification between them and those discourse communities. Generally, this implies detecting a symbol that viewers recognize as a stand-in for a specific community. A student might define "being Jewish" as one of her identities. Then, that student might choose the star of David as a symbol that shows affiliation. If that student includes the star of David in her selfie, some viewers would identify themselves as belonging to the same community, while others would not. This activity is based on Kenneth Burke's definition of identification. ${ }^{7}$

For the selfie on discursive formation, we refer back to the identity wheel. I ask students to imagine some visual and graphic features that they could link to their discourse communities: colors, shapes, backgrounds, phrases, images, objects, and so on. Once students decide on an object, they practice making that object the focal point of their selfies. The central aspect of a discursive formation selfie is that the object is the first thing that catches viewers' attention. Thus, in terms of speaking positions, the object is the speaking subject of the selfie. That object speaks of some identity trait of the person. This is the main difference between the selfies participating in classical discourses and the selfie participating in postmodern discourse. While in the previous three selfies the speaking subject is the person taking the selfie, in this selfie the speaking subject is an object. $^{8}$

Using class time to prepare for the final assignment is particularly positive: students feel they can share their learning among a supportive group that functions as their intended audience: potential "contacts" in social networks. It also stresses the point that learning is not exclusively an act of receiving information, but also one of creating new knowledge, particularly considering the novel phenomena of social media. At this point in the semester, and after this scaffolding structure, students feel ready to bring everything together and work on their final assignment. 
For the final assignment, in addition to taking four selfies, students compose four companion texts. The instructor, in this case, is the intended audience, since these texts provide evidence of students' rhetorical learning. The presence of these companion texts as part of the assignment is justified for two reasons. First, it involves students in a recursive and reflective writing process that addresses the goals of the Upper-Level Writing Requirement. Second, it gives students the opportunity to practice multimodality, creating meaningful links between visual and verbal rhetoric. While students' selfies communicate a direct message, companion texts give students the possibility to explain why those messages are relevant and need to be said. Companion texts work as reflections, and they foster personalized learning.

A potential stumbling block is that these companion texts might turn out to be quite didascalic: a description of what the student has done, rather than a reflection on the discursive purposes of the selfies. Particularly because there is a grade attached, students might be a bit shy in experimenting with forms of expression. To invite more experimentation, in future iterations of the course I plan to frame these companion texts around textual genres that reflect these discursive purposes. For the epideictic selfie, I will ask students to write an encomium: a piece of writing that praises the importance of the personal quality students show in the selfie. For the deliberative selfie, I will ask students to write a short argumentative essay that uses as thesis the claim they make in their selfies. Considering Figure 1 above, the student would write an essay trying to convince the audience that people should be serious in their recycling endeavors. For the forensic selfie, I will ask students to write a report on the community they identify with. For example, if a student chooses to identify with supporters of a specific sport team, that student will research the traits that those supporters share. Finally, for the postmodern selfie I will ask students to write a personal essay about the focal object. A personal essay is a very intimate and fluid genre, so students would use a discussion about an object to reveal how they see the world. Linking discursive purposes in visual and verbal rhetoric might strengthen student learning. ${ }^{9}$

The assignment "The Selfie Project" focuses on the selfie as an utterance that participates in rhetorical discourse. The assignment reinforces the idea that composition is inherent in any act of communication, no matter how quick and automatic that act is, and the assignment specifically engages with a composer's ethical appeal—how people skillfully present their character to an audience. Students engage in both analytical and productive work. To refer back to the larger goals of the course, a stronger understanding of rhetorical discourses helps students to become better "readers" of what people post on social media and to interpret nuanced purposes behind acts of communication. Similarly, practicing purposeful composition strategies allows students to strengthen their agency in their social media presence. As they post selfies, students would not just participate in social media, but engage in reflections, prove claims, and strengthen their sense of community. In short, this assignment invites students to become multimodal intellectuals and contribute to the public discourse that exists in virtual platforms. 


\section{The assignment-The Selfie Project}

See the Supplementary Files for this article at thepromptjournal.com for a PDF facsimile of the original formatting of this assignment.

For this assignment, you will create a media platform that includes 4 selfies, one for each of the rhetorical discourses introduced in class: good character, persuasion, identification, and discursive formation. Depending on your technological literacy, you can choose which platform you want to use. You can experiment with a website design platform, such as Wix or Wordpress, or you can simply use a presentation platform such as PowerPoint or Prezi.

Once you have chosen the 4 selfies you want to use for the project, you need to create a companion text for each selfie that offers a narrative linked to the message the selfies communicate. In these companion texts, you are asked to reflect on the particular rhetorical purpose of the selfies and on the socio-historical importance of what they represent (i.e., why is it important that you say what you say through your selfie?). Think of the companion text in this way: Let's suppose that you decide to express a deliberative argument with your selfie - specifically, that people should recycle. While you express that message with the selfie, you might not have the chance to tell your audience why recycling is a positive activity, because visual rhetoric is very direct. The companion text gives you that chance. These narratives will of course be personal, and you are encouraged to play with styles and forms: you can create your companion text as a personal essay, as a reflection about aspects of society, and even as a multimodal project such as a video or audio essay. It is important that in these companion texts you reference some of the studies we have read and discourses we have practiced in class, thereby showing a good grasp of the concepts learned. Each companion text should be between 250 and 500 words.

Finally, for accessibility, you need to create captions for each selfie that serve as descriptors.

Learning Objectives:

- To demonstrate the ability to interpret selfies as rhetorical utterances, using appropriate nomenclature

- To draft and revise selfies as multimodal texts

- To compose rhetorically effective selfies that purposefully present your character to an audience

Graded Components:

- Each selfie must participate in the appropriate rhetorical discourse. That is, you must show that you know how to engage in specific rhetorical practices

- Each companion text explains the importance of the message in the selfie, referencing readings and concepts introduced in class

- Your media platform must be free of glitches, so make sure that everything works 


\section{Appendix}

In order to offer teachers some guidance on how to evaluate students' selfies, I created this Appendix for Prompt readers based on what I do in class. This Appendix houses examples that I find particularly positive and that I share with my students as I introduce the assignment. You can consider this Appendix as a series of class notes.

\section{Good Character:}

The good character category can be observed when the subject of the selfie wants to convince the audience that he or she is a good person: for example, the subject shows him/herself with friends, or smiling, and so on.

An effective example can be found here.

For her project, this student collated her selfies in a Wix website. In this particular selfie, the student clearly engages in epideictic rhetoric, since her purpose is just to celebrate an aspect of her character. It is an impromptu moment caught on camera, revealing her true nature. In her companion text, this student reflects on how that aspect of her character is positive, thus acknowledging the benefits of presenting herself in that way. The addition of the color filter stresses the revision aspect of the composition process.

\section{Persuasion:}

The persuasion category occurs when the subject of the selfie wants to convince the audience of a specific character trait through some action. For example, the subject wants the audience to believe that traveling is a positive experience, or that doing charity work is a fulfilling activity, and so on, thus inviting the audience to partake in that activity.

A good example can be found here.

For her project, this student used the web-designing platform Wix. In this particular selfie, the student clearly engages in deliberative rhetoric. Her body stance suggests invitation, and the applied over-imposed caption offers a claim that is intended to convince her audience to do something: in this case, to have a home-cooked meal instead of eating out. Further, the addition of the caption is a clear example of different stages in composition: first take the picture, and then revise by adding a caption. Particularly praiseworthy is the companion text, which the student produced as an argumentative essay providing evidence to strengthen her claim. In the essay, the student follows the Toulmin model for argumentation based of Datum, Claim, and Warrant. The datum, or the information that the audience accepts as a fact, is that people eat three main meals a day; the claim, or the author's opinion, is that eating home-cooked meal is better; and the warrant, or what backs up the author's opinion, rests on the assumption that doing so is cheaper and healthier. 


\section{Identification:}

The identification category is present when the subject identifies with a specific community. Furthermore, the subject asks some members of the audience to identify with them. For example, the subject might wear some school garments, or they might be shown with a specific brand, so that the subject and the targeted audience can feel a connection with a lived experience.

A good example can be found here.

For her project, this student used the web-designing platform Weebly. In this particular selfie, the student engages in forensic rhetoric because the aspect of her character only becomes understood if the audience recognizes the social meanings of the colors "maize and blue" and the "block M." That is, those unexplained traits only work if the audience is already aware of their significance. Following Burke's definition of identification, the selfie also recreates some good-spirited trash talk. This identification with the University of Michigan creates a division between the community shared by the author and the audience and other communities that do not partake in the same discourse, in this case, students from the University of Maryland. The latter would not identify with her character because they would not be persuaded by the evidence she provides. Therefore, the combination of these elements makes the selfie a strong example of forensic discourse in the modern era. The forensic aspect is further strengthened by the addition of a link to a Youtube video in her companion text, advertising the university this student attends. In that video, the name of the university is never uttered, thus proving that there exists an implicit community that some audiences recognize and identify with.

\section{Discursive Formation:}

In the discursive formation category, the person is not at the center of attention in the selfie; rather, an object catches the targeted audience's primary attention. However, that object says something about the person's character. For example, when the focal point of the selfie is a book, that book tells us something about the character of the selfie's takers, who chose to show themselves through that specific book.

A good example can be found here.

For her project, this student used the presentation platform Prezi. In order to understand the discursive formation of this selfie, the audience needs to be aware of the relationship between the subject and a specific object in the picture, the hijab. The student is American, and in her everyday life she does not wear a hijab. Her social network is also not aware that she is Muslim. So, when viewers see the picture, the hijab becomes the focal point, and it captivates the audience's attention. In this case, the hijab is the object creating a discourse about the student. The hijab "speaks" about her, revealing aspects of her character that might not be known to her target audience. The qualities 
of the hijab represent a new and unexpected aspect of her identity: one that confers new meaning to her character for her intended audience.

Acknowledgements: I would like to thank all students who submitted their Selfie Projects, thus allowing me to test the assignment in a real classroom environment. In particular, I'd like to mention Kate Andriola, Autumn Coulter, Kaitlyn Eisenshtadt, Emily Glazer, and Tabassom Kalami for allowing me to showcase their work in the Appendix to this essay. The outcomes have been incredibly positive, and students noted a deep level of engagement in learning rhetorical strategies through everyday actions.

\title{
Notes
}

\begin{abstract}
${ }^{1}$ The category "discursive formation" was added because $20^{\text {th }}$ century rhetoric saw an important philosophical innovation in questioning the speaking subject. Classical discourses are based on the assumption that the person is the speaking subject. However, from Derrida to Foucault, $20^{\text {th }}$ century rhetoricians started to question the relationship between subjects and objects, simply wondering: "who speaks?" This relationship, postmodern rhetoric argues, creates new discursive formations. In visual rhetoric specifically, the viewer's attention might gravitate toward an object present in the image, rather than toward the person acting as the subject. However, that object acts as a metaphorical "ambassador" for the person's character. Thus, the object "speaks" for the subject.
\end{abstract}

${ }^{2}$ Here, I would like to acknowledge that many have utilized social media for pedagogical and rhetorical purposes. In particular, the journal Kairos has extensively published pieces on using social media in the classroom, both in PraxisWiki entries and in the Summer 2015 special issue on digital rhetoric and social media.

${ }^{3}$ A text that I found particularly useful in thinking about selfies and pedagogy is Elizabeth H. Buck's (2017) contribution to the collection Engaging 21 ${ }^{\text {st }}$ Century Writers with Social Media. There, Buck uses reception theory as "a meaningful way to understand and discuss social media composing practices" (Abstract). I decided not to include that text among class readings because its intended audience seems to be mostly academic scholars, so undergraduate students might find the reading quite complex.

${ }^{4}$ All excerpts are assigned from an anthology, The Rhetorical Tradition, edited by Bizzell and Herzberg (2001).

${ }^{5}$ In this case, the adjective "good" refers to what contemporary western societies consider as positive traits in a person: to be friendly is generally considered a good personal trait, as is to be playful or to be supportive.

${ }^{6}$ Here, we do not consider commentary captions that people could add to the selfies they post on social media. Although those captions are a huge part of the rhetoric of the image, they might be different based on specific networks. Someone might post a selfie and then caption it one way on Facebook, and post the same selfie with a different caption on Instagram. This is because students might interact with different audiences on those platforms: family on Facebook and friends on Instagram, for example. Here, we consider the selfie as a movable artifact: something that can be uploaded on several platforms.

${ }^{7}$ Burke comes up with three principles for identification: when author and audience feel consubstantial; when the community created by the author/audience differs from other communities; and when the author's belonging to a community is based on desire. 
${ }^{8}$ For a more detailed discussion about how students can interpret speaking positions in selfies participating in the four discourses, please refer to the Appendix to this essay.

${ }^{9}$ In the Fall 2017, I had the chance to implement these changes. To see how companion texts would work in this enhanced version of the assignment, please check the link to the project housing the deliberative example that you can find in the Appendix to this essay.

\section{References}

Bizzell, P., \& Herzberg, B. (2001). The rhetorical tradition: Readings from classical times to the present (2nd ed.). Boston, MA: Bedford/St. Martin's.

Buck, E. H. (2017). Slacktivism, supervision, and \#selfies: Illuminating social media composition through reception theory. In K. N. Bryant (Ed.), Engaging 21st century writers with social media (pp. 163-178). Hershey, PA: IGI Global.

Hughes, F. (2015). "Selfie". The New Yorker. Retrieved from https://www.newyorker.com/ magazine/2015/09/21/selfie-poetry-frieda-hughes

Karpathy, A. (2015). What a deep neural network thinks about your \#selfie. Retrieved from http://www.karpathy.github.io/2015/10/25/selfie/

Modery, L. (2015, August). Why we should "like" experiences-not selfies. Retrieved from http://www.hipstercrite.com/2015/08/18/why-we-should-like-experiences-not-selfies/

Saltz, J. (2014, January). Art at arm's length: A history of the selfie. Retrieved from http://www.vulture.com/2014/01/history-of-the-selfie.html 